(C) Я.І. Сливка, Ю.М. Савка, О.П. Кентеш, І.В. Бугір, 2019

УДК 612.821:371.7]-057.875-07

\title{
Дослідження психофізіологічного стану студентів з урахуванням ступеня напру- ження регуляторних систем
}

\author{
Я.І. Сливка, Ю.М. Савка, О.П. Кентеш, І.В. Бугір
}

E-mail: kaf-fiziolog@uzhnu.edu.ua

Ужгородський національний університет, медичний факультет, кафедра фізіології та патофізіології, Ужггород

\section{Реферат}

У ході дослідження виявлено взаємозв'язок між психофізіологічним станом студентів та їх адаптаційними можливостями. Як інтегральний показник ступеня функціонального напруження автономної нервової системи доцільно використовувати показник активності регуляторних систем (ПАРС), запропонований Р.М. Баєвським. Зростання значень показника активності регуляторних систем пов'язане з низкою змін у структурі варіабельності серцевого ритму, а саме: посиленням активності симпатичних впливів, зниженням впливу дихальної періодики, зростанням активності центральних регуляторних впливів. Встановлено, що студенти 3 незадовільним рівнем адаптації та виснаженням регуляторних механізмів характеризуються достовірно вищим рівнем особистісної тривожності, низькою стресостійкістю, зростанням рівня психосоматичних проявів.

Ключові слова: показник активності регуляторних систем, варіабельність серцевого ритму, дезадаптація, психосоматичні прояви.

Research of psychophysiological state of students using the degree of regulatory systems' tension Ya.I. Sluvka, Yu.M. Savka, O.P. Kentesh, I.V. Buhir.

Uzhhorod National University, medical faculty, department of physiology and pathophysiology, Uzhhorod

Abstract
The study revealed the relationship between the psychophysiological state of students and their adaptive abilities. The regulatory systems activity index (RSAI), proposed by RM Bayevsky, can be used as an integral measure of the functional stress of the autonomic nervous system. The increasing of RSAI level is associated with a number of changes in the structure of heart rate variability, such as increased activity of sympathetic nervous system, reduced respiratory periodicity, high index of centralization. It has been established that students with an unsatisfactory level of adaptation and depletion of regulatory mechanisms are characterized by a significantly higher level of personal anxiety, low stress stability, increased psychosomatic manifestations.

Key words: regulatory systems activity index, heart rate variability, disadaptation, psychosomatic manifestations.

Вступ. Постійна інтенсифікація навчального процесу у вищому навчальному закладі - це складний та тривалий процес, який суттєво впливає на психофізіологічні параметри організму молодої людини. Особливу категорію серед студентської молоді становлять студенти-медики початкових курсів, які зазнають підвищеного психоемоційного впливу, пов'язаного зі зміною режиму праці та відпочинку, з необхідністю адаптації до умов навчальної діяльності, збільшенням та складністю навчального матеріалу.

Високий рівень психоемоційної та інтелектуальної напруги, підвищення вимог до якості знань, порушення рухового режиму негативно впливає на функціональні можливості організму студентів, що призводить до напруження механізмів центральної адаптації [1]. Внаслідок цього знижуються адаптаційні резерви організму, порушуються механізми регуляції автономних функцій, створюються передумови до психоемоційного напруження, виникнення психосоматичних проявів [2,3].

Для діагностики функціонального стану автономної нервової системи (АНС) сьогодні активно використовується в практиці метод аналізу варіа- бельності серцевого ритму (ВСР) $[4,5,6]$ та запропонований Р.М. Баєвським [7] інтегральний показник оцінки адаптаційних можливостей організму показник активності регуляторних систем (ПАРС).

Останнім часом зростає інтерес до застосування ПАРС у клінічній та відновлювальній медицині $[4,8,9]$, оскільки він дозволяє характеризувати не тільки ступінь напруження адаптаційних механізмів та вихідний функціональний стан організму, а i його адаптаційні можливості при зміні умов навколишнього середовища та комплексно оцінити стресорний ефект подразнюючих факторів на організм людини.

Наразі недостатньо вивченим залишається питання оцінки адаптаційних можливостей АНС 3 урахуванням ПАРС та його взаємозв'язок 3 психофізіологічними показниками здоров'я студентів.

Мета дослідження: визначити взаємозв'язок між психофізіологічними показниками та ступенем напруження регуляторних систем 3 урахуванням ПАРС.

Матеріали та методи. У дослідженні брали участь 86 студентів другого та третього курсу віком від 18 до 20 років, які не мали відхилень від 
норми за даними фізикального обстеження і професійно не займались спортом. Дослідження проводили у міжсесійний період (жовтень-грудень), не пов'язаний зі складанням заліків та іспитів.
Оцінку функціонального стану АНС здійснювали методом кардіоінтервалографії (КІГ) 3 аналізом спектральних показників ВСР за допомогою апаратно-програмного комплексу «Кардіолаб» (рис.1).

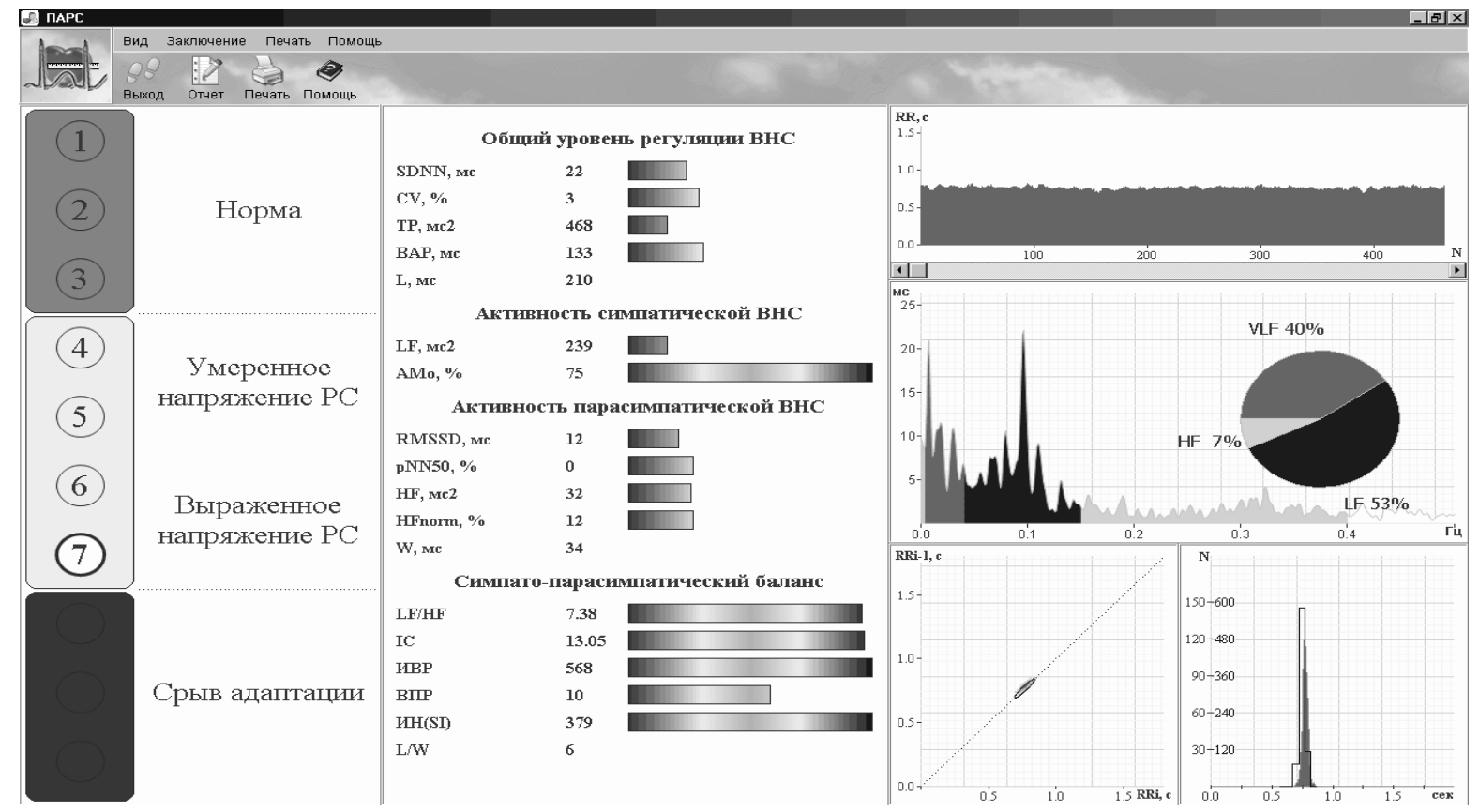

Рис. 1. Комп’ютерна обробка ритмокардіограми студента Б. за допомогою приладу «Кардіолаб»

Методика реєстрації та комп’ютерного аналізу ВСР виконувалась у відповідності з прийнятими міжнародними стандартами аналізу варіабельності серцевого ритму [5,6], а також за Р.М. Баєвським [7]. Визначались спектральні показники ВСР: ТР, мс $^{2}$ (Totalpower) - загальна потужність спектру BCP; VLF\% (VeryLowFrequency) - активність вищих надсегментарних центрів автономної регуляції та гуморально-метаболічних впливів; LF\% (LowFrequency) - активність симпатичних модуляторів; HF\% (HighFrequency) - пов'язаний із вагусними впливами; LF/HF - симпатовагальний баланс; IC - індекс централізації.

Комплексна оцінка вегетативного гомеостазу проводилась за ПАРС, який розраховується за спеціальним алгоритмом [7].

Так, на основі ПАРС, виділяють три функціональні стани здоров'я, які ще називають системою «Світлофор»: зелена зона - стан норми або стан задовільної адаптації; жовта зона - напруження чи перенапруження механізмів адаптації та червона зона - зрив адаптації.

Оцінка психофізіологічного стану студентів включала: визначення рівня ситуативної та особистісної тривожності за тестовою методикою Спілбергера-Ханіна; оцінка рівня стресостійкості [10]; дослідження психосоматичної обумовленості соматичних недомагань за Гісенівським опитувальником (GiesenerBeshwedebogen
GBB)[10]. Гісенівський опитувальник (Giesener Beshwedebogen) - анкета, що призначена для виявлення суб'єктивної картини фізичних недомагань. Оцінювались чотири основні та одна додаткова шкала:

Шкала 1. «Виснаження» (В) - характеризує неспецифічний фактор виснаження, що вказує на загальну втрату життєвої енергії, потребу в допомозі.

Шкала 2. «Шлункові скарги» (Ш) - відображає синдром нервових (психосоматичних) шлункових недомагань.

Шкала 3. «Ревматичний характер» (Р) - відображає суб'єктивні страждання пацієнта, що мають спастичний характер.

Шкала 4. «Серцеві скарги» (С) - вказує на те, що пацієнт локалізує свої недомагання здебільшого в серцево-судинній сфері.

Шкала 5. «Інтенсивність скарг» або «Тиск» (Т) - характеризує загальну інтенсивність скарг.

У всіх обстежуваних вимірювалися частота дихання (ЧД), частота серцевих скорочень (ЧСС) та артеріальний тиск (АТ).

Результати досліджень та їх обговорення. Результати дослідження показали, що серед обстежуваного контингенту в 45\% студентів виявлено стан задовільної адаптації, у 43\% - стан функціонального напруження i незадовільна адаптація виявлена у $12 \%$ студентів (рис. 2 ). 


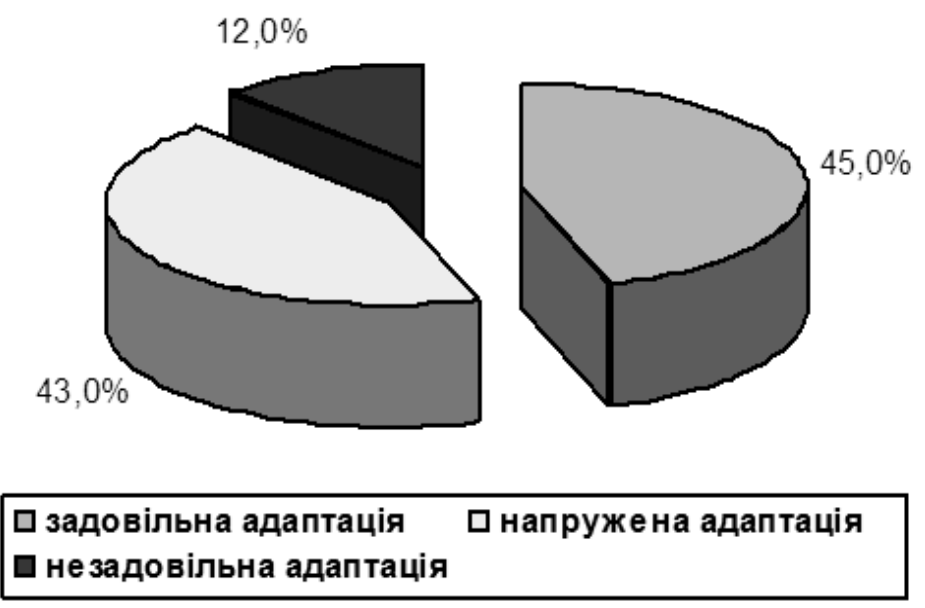

Рис. 2. Розподіл студентів за ПАРС

На наступному етапі дослідження проведено порівняльний аналіз показників ВСР у студентів з урахуванням ПАРС (табл. 1).

Таблиця 1

Характеристика спектральних показників ВСР з урахуванням функціонального стану регуляторних систем студентів $(\mathrm{M} \pm \mathrm{m})$

\begin{tabular}{|c|c|c|c|c|c|}
\hline Показники & $\begin{array}{c}\text { Задовільна адаптація } \\
(45 \%) \\
1\end{array}$ & $\begin{array}{c}\text { Напружена адаптація } \\
(43 \%) \\
2\end{array}$ & P $1-2$ & $\begin{array}{c}\text { Незадовільна адап- } \\
\text { тація } \\
(12 \%) \\
3\end{array}$ & P $1-3$ \\
\hline $\mathrm{TP}, \mathrm{Mc}^{2}$ & $3557,7 \pm 315,2$ & $3963,9 \pm 474,1$ & - & $4727,9 \pm 746,9$ & - \\
\hline VLF, $\mathrm{Mc}^{2}$ & $990,9 \pm 131,1$ & $961,8 \pm 140,3$ & - & $870,4 \pm 80,8$ & - \\
\hline VLF, \% & $27,8 \pm 2,0$ & $24,3 \pm 2,3$ & - & $18,5 \pm 2,5$ & $<0,01$ \\
\hline $\mathrm{LF}, \mathrm{Mc}^{2}$ & $1415,6 \pm 170,5$ & $1941,9 \pm 311,8$ & - & $2740,2 \pm 454,5$ & $<0,05$ \\
\hline $\mathrm{LF}, \%$ & $39,8 \pm 2,5$ & $48,6 \pm 2,9$ & $<0,05$ & $57,8 \pm 4,2$ & $<0,01$ \\
\hline $\mathrm{HF}, \mathrm{Mc}^{2}$ & $1138,3 \pm 73,3$ & $1073 \pm 55,8$ & - & $1134,2 \pm 63,8$ & - \\
\hline HF, \% & $32,1 \pm 1,6$ & $27,1 \pm 1,3$ & $<0,05$ & $24 \pm 1,3$ & $<0,01$ \\
\hline $\mathrm{LF} / \mathrm{HF}$ & $1,4 \pm 0,1$ & $1,8 \pm 0,2$ & $<0,05$ & $2,6 \pm 0,3$ & $<0,01$ \\
\hline $\mathrm{IC}$ & $2,7 \pm 0,3$ & $2,8 \pm 0,6$ & - & $3,4 \pm 0,9$ & - \\
\hline
\end{tabular}

Примітки: Р1-2 - достовірність різниці показників у групах 1 та 2; Р1-3 - достовірність різниці показників у групах 1 та 3.

Оцінка показників дозволила встановити, що із збільшенням ступеня напруження регуляторних систем від задовільної до незадовільної адаптації спостерігається достовірне зменшення показників VLF, \%, HF, \% та зростання показників LF, мc $^{2}$, LF,\%, LF/HF. Збільшення потужності спектру низькочастотного компоненту та зниження потужності високочастотного компоненту ВСР вказує на зростання рівня активності вазомоторного центру та підвищення активності симпатичної ланки регуляції серцево-судинної системи.

На наступному етапі дослідження у студентів 3 різними адаптаційними можливостями проведено оцінку низки психофізіологічних параметрів (табл. 2).
Встановлено, що у студентів із незадовільним рівнем адаптації та виснаженням регуляторних механізмів спостерігаються більш високі показники ЧСС, систолічного, діастолічного тиску, ЧД порівняно із станом задовільної та напруженої адаптації. У студентів із незадовільним рівнем адаптаційних можливостей відзначено вищий рівень особистісної тривожності та низький рівень стресостійкості в порівнянні з групою задовільної адаптації. Особистісна тривожність розглядається як стійка індивідуальна особливість людини, що характеризує іiі тенденцію сприймати певний діапазон індиферентних ситуацій як загрозливих, небезпечних для самооцінки і самоповаги. Високотривожні особистості схильні сприймати загрозу самооцінці і життєдіяльності та реагувати вираженим станом тривоги. Підви- 
щена тривога є основним механізмом неадаптивної поведінки, однак, певний рівень тривожності - природна й обов'язкова особливість продуктивної активності людини. Самоконтроль і самооцінка цього стану є істотним компонентом адаптивної саморегуляції, позаяк підвищений рівень тривоги $є$ провідним «облігатним механізмом» дезадаптивних розладів.

Таблиця 2

Психофізіологічні параметри з урахуванням функціонального стану регуляторних систем студентів $(\mathrm{M} \pm \mathrm{m})$

\begin{tabular}{|l|c|c|c|}
\hline \multicolumn{1}{|c|}{ Показники } & Задовільна адаптація $(\mathrm{n}=45 \%)$ & $\begin{array}{c}\text { Напружена адаптація } \\
(\mathrm{n}=43 \%) \\
2\end{array}$ & $\begin{array}{c}\text { Незадовільна адаптація } \\
(\mathrm{n}=12 \%) \\
3\end{array}$ \\
\hline ЧСС, за хв.. & 1 & $83 \pm 3,1$ & $95 \pm 6,5^{* *}$ \\
\hline САТ, мм рт.ст. & $119 \pm 2,3$ & $125 \pm 4,3$ & $134, \pm 5,3^{*}$ \\
\hline ДАТ, мм рт.ст. & $72,7 \pm 1,4$ & $79,4 \pm 2,5$ & $84,3 \pm 4,5^{*}$ \\
\hline ЧД, за хв. & $15,2 \pm 0,7$ & $17,2 \pm 0,9$ & $19,7 \pm 1,9^{*}$ \\
\hline $\begin{array}{l}\text { Особистісна } \\
\text { тривожність }\end{array}$ & $31,7 \pm 4,4$ & $46,1 \pm 4,2$ & $52,7,2 \pm 5,3^{* *}$ \\
\hline Стресостійкість & $18 \pm 3,7$ & $32 \pm 4,3$ & $47 \pm 4,8^{* *}$ \\
\hline
\end{tabular}

Примітки: * - достовірність різниці показників у групах 1 та $3, \mathrm{p}<0,05$; ** - достовірність різниці показників у групах 1 та $3, \mathrm{p}<0,01$.

Аналіз результатів інтенсивності психосоматичних недомагань за Гісенівським опитувальником (табл. 3) показав, що достовірно вищі середні ве- личини психосоматичних недомагань за всіма шкалами були виявлені у групі студентів із незадовільною адаптацією.

Таблиця 3

Інтенсивність психосоматичних скарг у студентів з урахуванням функціонального стану регуляторних систем $(\mathrm{M} \pm \mathrm{m})$

\begin{tabular}{|l|c|c|c|}
\hline Показники & $\begin{array}{c}\text { Задовільна адаптація } \\
(\mathrm{n}=45 \%)\end{array}$ & $\begin{array}{c}\text { Напружена адаптація } \\
(\mathrm{n}=43 \%)\end{array}$ & $\begin{array}{c}\text { Незадовільна адаптація } \\
\left(\mathrm{n}=12^{\%}\right)\end{array}$ \\
\hline Виснаження & $5,3 \pm 0,6$ & $8,8 \pm 2,1$ & $12,5 \pm 2,5^{* *}$ \\
\hline Шлункові & $1,8 \pm 0,3$ & $2,7 \pm 1,3$ & $4,7 \pm 1,3^{*}$ \\
\hline Ревматичні & $4,4 \pm 1,4$ & $5,5 \pm 1,5$ & $8,7 \pm 3,5^{*}$ \\
\hline Серцеві & $2,4 \pm 0,7$ & $2,9 \pm 0,9$ & $5,5 \pm 1,9^{*}$ \\
\hline Тиск & $11,7 \pm 3,4$ & $21,1 \pm 4,2$ & $32,2 \pm 4,3^{* *}$ \\
\hline
\end{tabular}

Примітки: * - достовірність різниці показників у групах 1 та $3, \mathrm{p}<0,05 ; * *$ - достовірність різниці показників у групах 1 та $3, \mathrm{p}<0,01$.

Отримані результати дослідження дають підстави стверджувати, що середні показники інтенсивності психосоматичних скарг мають достовірні відмінності у групах із різним ступенем напруження регуляторних механізмів. Так, у осіб із незадовільною адаптацією за всіма без винятку шкалами середні величини психосоматичних скарг були достовірно вищими і становили $\mathrm{p}<0,05$ за шкалами «Шлункові», «Ревматичні», «Серцеві» та $\mathrm{p}<0,01$ за шкалами «Виснаження» та «Тиск».

Висновки. 1. У результаті дослідження показників ВСР в умовах звичайного навчального навантаження серед студентів виявлено різні функціональні стани за інтегрованим показником активності регуляторних систем. Залежно від функціональних резервів регуляторні системи працюють із різним ступенем напруження від оптимального до перенапруження. Показано, що при збільшенні напруження механізмів адаптації посилюється активність симпатичних впливів, знижується вплив дихальної періодики.

2. Встановлено, що студенти 3 незадовільним рівнем адаптації та виснаженням регуляторних механізмів характеризуються достовірно вищим рівнем особистісної тривожності, низькою стресостійкістю.

3. Встановлено взаємозв'язок між наростанням рівня психосоматичних проявів та зниженням функціональних резервів механізмів адаптації. 
Інформація про конфлікт інтересів. Автори заявляють про відсутній конфлікт інтересів при виконанні даного наукового дослідження та підготовці даної статті.

Інформація про фінансування. Автори гарантують, що вони не отримували жодних винагород у будь-якій формі, здатних вплинути на результати роботи.

\section{Список використаної літератури}

1. Antonets KV, Churukova NM. Vlyianye uchebnoi nahruzky na nekotorыe parametru hemodynamyky y эmotsyonalnoe sostoianye studentov. Mezhdunarodnыi studencheskyi nauchnыi vestnyk. 2017;2. Availablefrom: http://www.eduherald.ru/ru/article/view?id=16912. [In Russian].

2. Tretiak TO, Severynovska OV. Psykhofiziolohichnyi profil studentiv pershoho kursu u protsesi adaptatsii do osvitnoi diialnosti. Naukovi zapysky Ternopilskoho natsionalnoho pedahohichnoho universytetu im. Volodymyra Hnatiuka. Seriia: Biolohiia. 2016;2(66):90-103. [In Ukrainian].

3. Fedotova HH, Pozharova HV, Heraskyna MA. Otsenka funktsyonalnoho sostoianyia orhanyzma studentov na osnove analyza varyabelnosty serdechnoho rytma. Sovremennыe problemы nauky y obrazovanyia. 2015;5:Availablefrom: https://www.scienceeducation.ru/ru/article/view?id=22587. [In Russian].

4. Horst NA, Lыchahyna SN, Horst VR, Horiachkyna LV. Pokazatel aktyvnosty rehuliatornыkh system v strukture analyza varyabelnosty serdechnoho rytma. Estestvennыe nauky. Fyzyolohyia. 2016; 1(54): 28-33. [In Russian].

5. Yabluchanskyi NY, Martыnenko AV, Ysaeva AS. Yssleduem rehuliatornыe protsessы. Donetsk : ChP Butasova; 2005. 96 s. [In Russian].

6. Heart rate variability: Standards of measurement, physiological interpretation and clinical use. Task Force of European Society of Cardiology and the North American Society of Pacing and Electrophysiology. Circulation. 1996; 5:1043-65.

7. Baevskyi RM, Yvanov HH. Varyabelnost serdechnoho rytma: teoretycheskye aspektы y vozmozhnosty klynycheskoho prymenenyia. Medytsyna. 2000; 295: 9. [In Russian].

8. Lytvynets L.Ya. Variabelnist sertsevoho rytmu yak indykator adaptyvnykh mozhlyvostei u ditei z bronkhialnoiu astmoiu. Semeinaia medytsyna. 2013; 3: 131-34. [In Ukrainian].

9. Lebedenko AA, Tarakanova TD, Kozyreva TB, Kasian MS, Nosova EV, Maltsev SV, et al. The spectral analysis of heart rate variability - a new view on the problem of autonomic dysfunction in children with asthma. Medical Herald of the South of Russia. 2013;(1): 37-41.

10. Malkyna-Pykh Y. H. Psykhosomatyka: Spravochnyk praktycheskoho psykholoha. M.: Yzd-vo Eksmo; 2005. 992 s. [In Russian].

Стаття надійшла до редакції: 18.03 .2019 р. 